\title{
불곡산의 식생
}

\author{
이 상 훈 심 재 국 \\ 중앙대학교 생명과학과
}

\section{Vegetation of Mt. Bulgok}

\author{
LEE, Sang-Hoon $\cdot$ Jae-Kuk SHIM \\ Department of Life Science, Chung-Ang University
}

\begin{abstract}
The forest vegetation of Mt. Bulgok was surveyed from November 2017 to December 2017. The vegetation of Mt. Bulgok was classified into following 16 plant communities by physiognomic dominant species method: $Q$. serrata- $Q$. mongolica community, $Q$. acutissima-Q serrata community, $Q$. acutissima community, $Q$. serrata- $Q$. acutissima community, $Q$. variabilis- $Q$. serrata community, $P$. rigida community, $Q$. acutissima-C. crenata community, L. leptolepis community, $Q$. acutissima- $R$. pseudoacacia community, $Q$. mongolica community, $R$. pseudoacacia community, $R$. pseudoacacia$Q$. acutissima community, $Q$. mongolica- $Q$. serrata community, $P$. koraiensis community, C. crenata community, C. crenata-P. rigida community, Prunus serrulata var. spontanea community. The $Q$. serrata- $Q$. mongolica communities accounted for about $30.0 \%$ of the whole survey area. The $Q$. acutissima community occupied $18.6 \%$ of the survey area and was distributed in the second largest area. The $Q$. acutissima- $Q$. serrata community occupied $16.2 \%$ of the area. The vertical structure of the major plant communities of Mt. Bulgok represented four layers. The height and coverage of each layer at different plant community showed vary appearances depending on the type of vegetation. The frequency distribution of DBH-sizw class showed that the $Q$. serrata-Q. mongolica community, $Q$. acutissima-Q. serrata community and $Q$. acutissima community will be maintained unless the external interference. The degree of green naturality(DGN) 7 was $81.0 \%$ of the area, $12.8 \%$ in DGN 6 and $6.2 \%$ in DGN 2. The net primary productivity (NPP) was assumed as $1,450.81 \mathrm{~g} / \mathrm{m}^{2} / \mathrm{yr}$ (use temp.) by Miami model, and $1,457.30 \mathrm{~g} / \mathrm{m}^{2} / \mathrm{yr}$ by Montreal model, respectively. In order to preserve and restore the natural vegetation of Mt. Bulgok, it is necessary to control the visitor's proper access, excessive development restraint, and continuous monitor and positive management of naturalized plants.
\end{abstract}

Key words : vegetation, plant community, DBH-class, Mt. Bulgok

\section{서 론}

불곡산은 북위 $37^{\circ} 21^{\prime} 05^{\prime \prime}$, 동경 $127^{\circ} 07^{\prime} 59^{\prime \prime}$ 에 위치한 표고 $345 \mathrm{~m}$ 의 산으로 경기도 성남시 분당구 
정자동, 구미동과 광주시 오포읍에 걸쳐 있다. 불곡산은 서쪽으로는 경부고속도로와 분당, 수지 지역 에 의하여 남쪽으로는 43번 도로와 골프장들에 의하여, 동북쪽으로는 57번 도로와 주거지에 의하여 고립되어 있다. 또한 57번 도로에 의하여 좁게 단절되어 있으나, 한국지역난방공사 분당사업소 뒷편 에서 가까스로 분당율동공원을 통하여 고불산과 연결될 수 있다.

분당 지역의 옛 지명에서는 큰절골과 작은절골 등에 절터가 있어 불곡산이라 하였다고 전해진다. 또, 정자동 웃마을 주민들이 이 산을 성스러운 산으로 여기고 산신제를 지낸 것에서 유래하여 성덕 산(聖德山)이라고도 하고, 현지에서는 효종산(孝鐘山)이라고도 한다(http://www.grandculture.net/main/ main.asp). 불곡산은 영장산과 함께 성남시에서 지정한 등산로이며, 곳곳에 공원시설과 운동시설들이 자리하여 등산객과 방문객의 출입이 잦은 편이다. 불곡산의 등산로는 북쪽으로는 태현과 새마을고개 를 지나 새나리고개 - 곧은골고개 - 갈마치고개로 이어지고, 남한산성 지대와도 연결된다. 남쪽으로는 성남시와 광주시 오포읍·용인시 수지지역이 경계를 이루는 대지산으로 연결된다.

불곡산은 동쪽과 서쪽의 지형이 대조적인데, 주로 성남시 분당구에 해당하는 불곡산의 서쪽 사면 은 광주시 오포읍에 해당하는 동쪽 사면에 비해 경사가 급하고 산세가 험하다. 동쪽 사면은 완만한 산지와 골짜기로 이루어져 있어 주택과 농경지가 골짜기를 따라 산 속 깊숙이 자리하고 있는 경우가 많다.

본 연구는 한국자연보전협회의 2017년도 불곡산 일대 생태계 종합학술조사 계획의 일환으로 식물 생태 부분의 결과를 보고하고자 수행되었으며, 식생 분야에 관한 현장조사를 수행하고, 그 결과를 기 술하였다. 이러한 결과들은 생태계의 생물다양성의 실체파악과 훼손된 지역의 생태계 복원에 대한 생태학적 자료 확보와 이를 통한 자연환경보전의 기초자료로 활용되어질 것으로 기대되어지며, 국가 생태 자원의 보존에 있어 참고할 수 있을 것으로 판단된다.

\section{조사 방법}

조사는 2017년 11월부터 2017년 12월에 걸쳐 수행하였다. 조사는 불곡산과 그 주변을 조사 범위로 하였다(Fig. 1).

식생조사 방법은 조사지 내에 8개소의 지점에 대하여 적정 크기의 방형구를 설치하고, 흥고직경 $2 \mathrm{~cm}$ 이상의 수목을 대상으로 교목층과 아교목층의 수목에 대하여 매목 조사를 실시하였으며, 출현 종에 대하여 우점도와 사회도를 조사하고 기록하였다. 매목조사 시 흥고(1.2m) 이하에서 분지한 맹아 지는 독립된 개체로 판단하여 조사결과 및 분석에 반영하였다.

식생조사표에 근거하여 주요 군락의 층별 식피율 분포도를 작성하였으며, 주요 군락에서의 수종 별 DBH Class 빈도 분포도를 작성하였다.

식생조사 시 식생단위는 상관을 근거로 동정하였고, 식물군락의 명칭은 우점종의 종명을 따라 명 명하였으며, 혼합 식분은 상위 우점종 1 2종을 연기하였다. 또한 조사지의 현존식생도와 녹지자연 도를 $1 / 5,000$ 축적의 수치지형도에 도면화 하였다.

조사지역이 위치한 지역과 가까운 서울지역의 기상대의 과거 30년(1981 2010) 간의 기후자료를 바탕으로 Climate diagram을 작성하였고, 최저기온, 평균기온, 최고기온, 강수량, 증발량, 일조시간 등 
기후요소를 조사하였다.

한편, 조사지역과 가까운 서울지역을 대상으로 Miami Model과 Montreal Model에 의한 순생산량을 추정하였다(임, 1982).

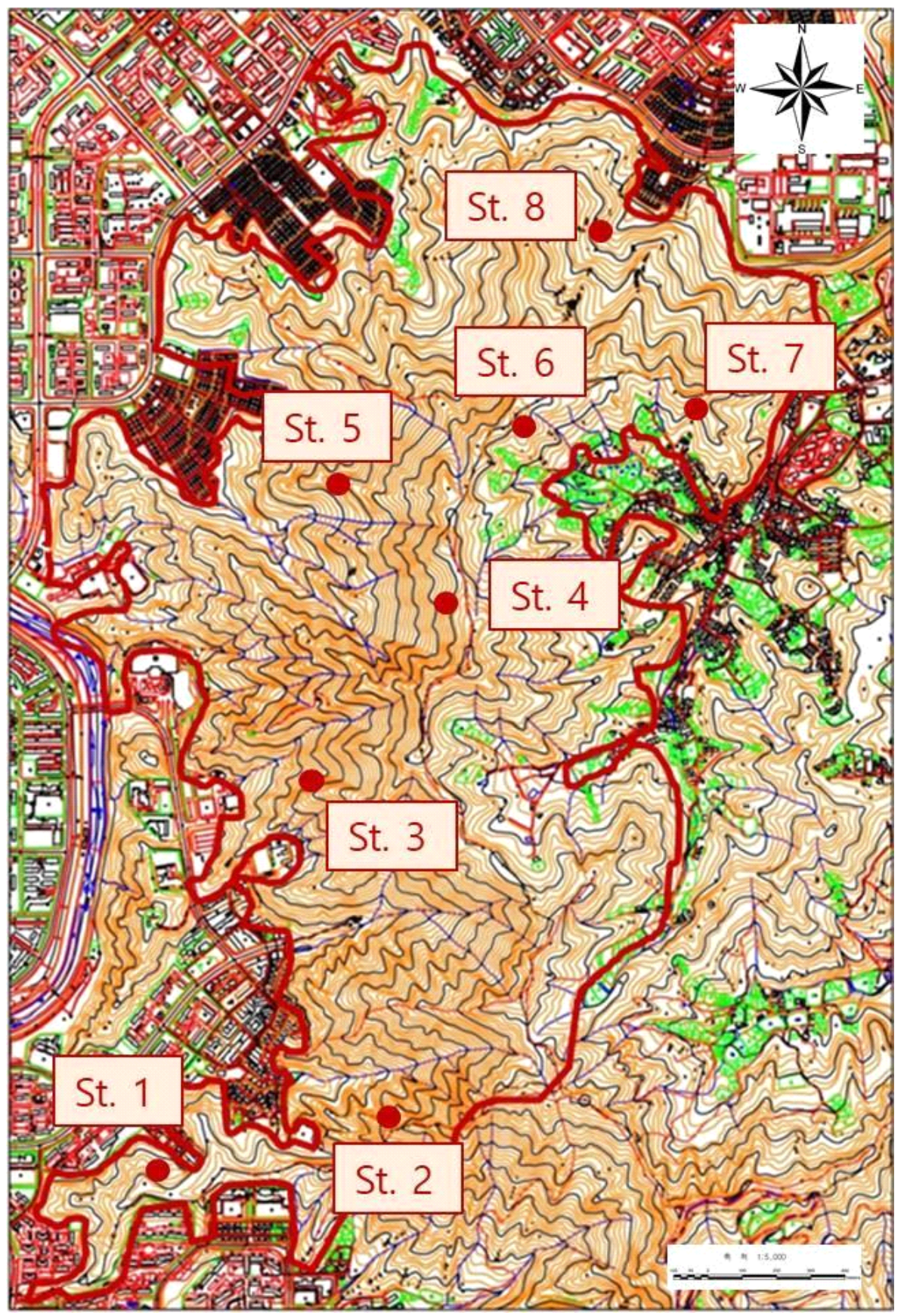

Fig. 1. Map showing the surveyed sites and area in Mt. Bulgok. 


\section{결 과}

\section{1. 조사지의 기후 개황}

기상청(www.kma.go.kr, 1981 2010년 자료)에 따르면 불곡산과 가까운 서울지역의 연평균기온은 $12.5^{\circ} \mathrm{C}$, 연 평균강수량은 $1,450.6 \mathrm{~mm}$, 총일조시간은 $172.2 \mathrm{hr}$ 으로 나타났다(Table 1). 증발량은 연간 $1,093.8 \mathrm{~mm}$ 로서 연강수량보다 $356.8 \mathrm{~mm}$ 낮지만, 7월부터 9월에 걸친 3개월간을 제외하면 강수량보다 큰 값을 나타내었다. 월평균최저기온은 1 월로 월평균기온 $-5.9^{\circ} \mathrm{C}$ 를 기록하였으며, 12 월부터 이듬해 2 월까지는 최저기온이 영하로 내려가고, 30 년 중 가장 낮은 일평균기온은 $-18.6^{\circ} \mathrm{C}$ 인 것으로 나타났 다(Fig. 2).

Table 1. The climatic factors of Mt. Bulgok. Data from Seoul Meteorological Station (Recent 30 years; 1981 2010)

\begin{tabular}{lrrrrrrccccccr}
\hline & $\mathrm{J}$ & \multicolumn{1}{c}{$\mathrm{F}$} & $\mathrm{M}$ & $\mathrm{A}$ & \multicolumn{1}{c}{$\mathrm{M}$} & $\mathrm{J}$ & $\mathrm{J}$ & $\mathrm{A}$ & $\mathrm{S}$ & $\mathrm{O}$ & $\mathrm{N}$ & $\mathrm{D}$ & Mean \\
\hline Maximum air temp. $\left({ }^{\circ} \mathrm{C}\right)$ & 1.5 & 4.7 & 10.4 & 17.8 & 23 & 27.1 & 28.6 & 29.6 & 25.8 & 19.8 & 11.6 & 4.3 & 17.0 \\
Mean air temp. $\left({ }^{\circ} \mathrm{C}\right)$ & -2.4 & 0.4 & 5.7 & 12.5 & 17.8 & 22.2 & 24.9 & 25.7 & 21.2 & 14.8 & 7.2 & 0.4 & 12.5 \\
Minimum air temp. $\left({ }^{\circ} \mathrm{C}\right)$ & -5.9 & -3.4 & 1.6 & 7.8 & 13.2 & 18.2 & 21.9 & 22.4 & 17.2 & 10.3 & 3.2 & -3.2 & 8.6 \\
Precipitation(mm) & 20.8 & 25 & 47.2 & 64.5 & 105.9 & 133.2 & 394.7 & 364.2 & 169.3 & 51.8 & 52.5 & 21.5 & $1,450.6$ \\
Evaporation(mm) & 37.5 & 46.6 & 82.8 & 123 & 141.4 & 139.2 & 110.8 & 123.3 & 107.3 & 89.3 & 53.2 & 39.4 & $1,093.8$ \\
Duration of sunshine(hr) & 160.3 & 163.3 & 189 & 205 & 213 & 182 & 120 & 152.5 & 176.2 & 198.8 & 153.2 & 152.6 & 172.2 \\
\hline
\end{tabular}

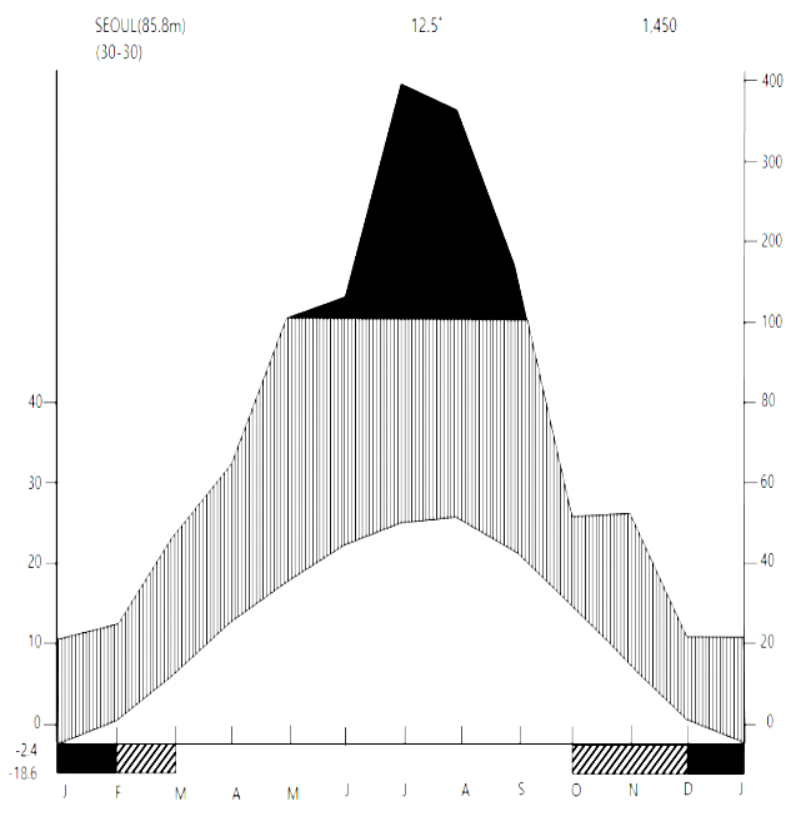

Fig. 2. Climate diagram of Mt. Bulgok. Data from Seoul Meteorological Station (Recent 30 years; 1981 2010). 


\section{2. 식생의 특징}

조사 지역인 불곡산이 자리한 경기도 중부지방은 식물구계 지리학상으로 한반도 중부아구(임과 이, 1978)에 속하고, 식생은 냉온대 중부(Yim and Kira, 1975)에 해당한다.

환경부에 의해 작성된 불곡산과 그 주변의 생태 - 자연도를 살펴보면 대부분의 산림지역은 참나무 류가 우점하는 생태보전등급 2급 지역이며, 불곡산 정상과 정상에서 형제산에 이르는 능선의 서쪽 일부가 1 등급 지역으로 지정되어 있음을 알 수 있다(Fig. 3).

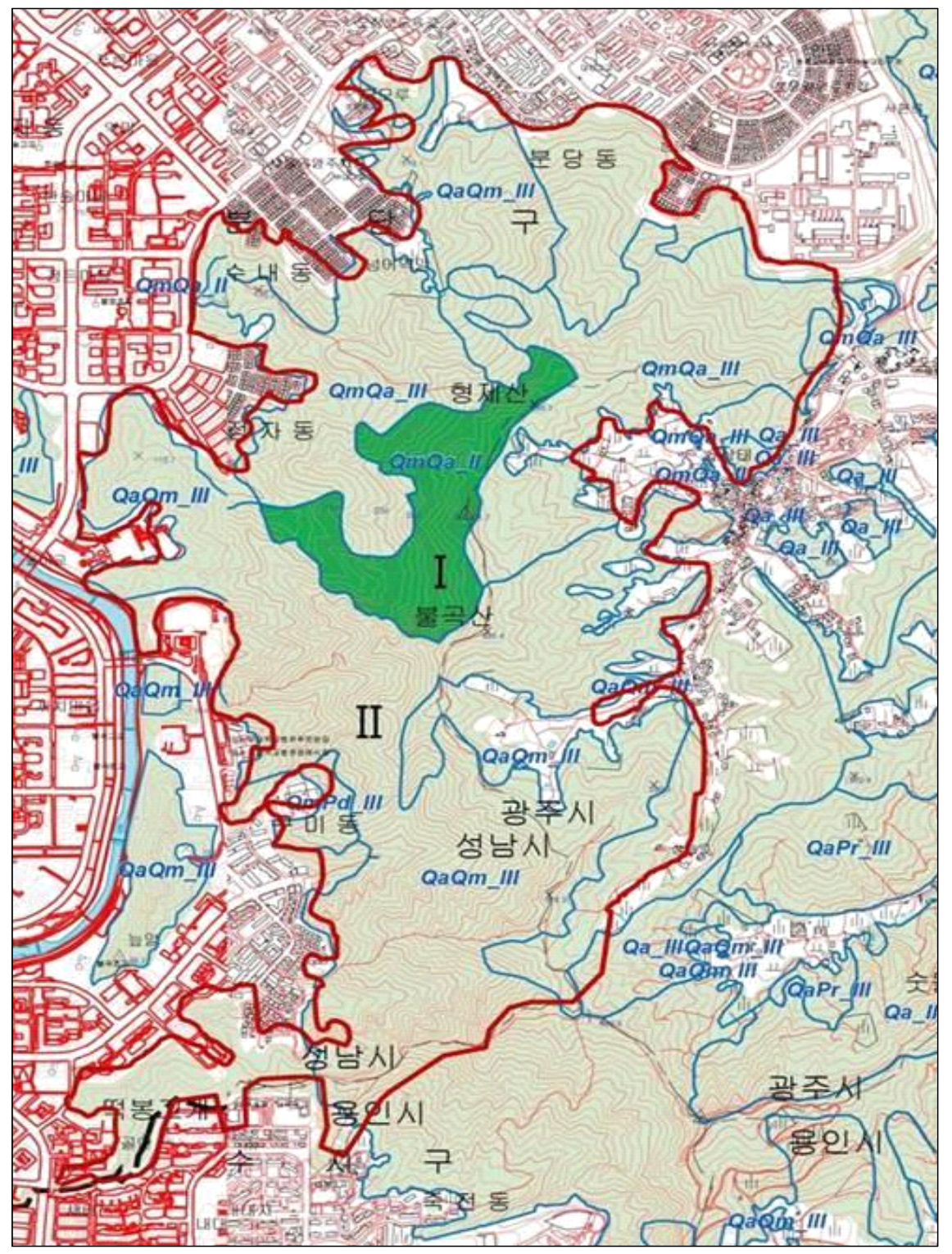

Fig. 3. Ecological zoning (Degree of ecological naturality) map of Mt. Bulgok. (from Ministry of Environment, www.egis.me.go.kr/). 


\section{1) 주요 군락의 분포}

불곡산의 식생은 주로 참나무속(Quercus)의 졸참나무(Q. serrata), 상수리나무(Q.acutissima), 신갈나 무(Q.mogolica), 굴참나무(Q. variabilis) 등의 수종이 순림 또는 혼효림으로 분포하고, 산림과 도심의 경계부근에 리기다소나무(Pinus rigida), 일본잎갈나무(Larix leptolepis), 밤나무(Castanea crenata), 잣나 무(P. koraiensis) 등의 식재수종이 참나무류와 함께 분포한다. 군락별 분포면적을 살펴보면 졸참나무신갈나무군락(Q. serrata-Q. mongolica community)가 전체 조사면적의 약 $30.0 \%$ 를 차지하여 가장 넓게 분포하였다. 상수리나무군락(Q. acutissima community)은 조사면적의 $18.6 \%$ 에 차지하여 두 번째로 넒 은 면적에 분포하였다. 세 번째로는 상수리나무-졸참나무군락(Q. acutissima-Q. serrata community)으 로 $16.2 \%$ 의 점유면적을 나타내었다. 졸참나무-상수리나무군락(Q. serrata-Q. acutissima community)이 $5.0 \%$, 굴참나무-졸참나무군락(Q. variabilis-Q. serrata community)이 $4.9 \%$, 리기다소나무군락(Pinus rigi$d a$ community)이 $4.3 \%$, 상수리나무-밤나무군락(Q. acutissima-C. crenata community)이 $3.2 \%$, 아까시나 무-상수리나무군락(Robinia pseudoacacia-Q. acutissima community)이 $2.3 \%$, 일본잎갈나무군락(Larix leptolepis community)이 $2.3 \%$ 의 면적을 차지하였다. 한편 불곡산 조사지역의 전체면적에서 경작지와 초지 등이 차지하는 비율은 $6.2 \%$ 를 나타내었다.

이들 우점종 상관에 따라 구분된 식생을 도면화한 식생도는 Fig. 4와 같다.

Table 2. Physiognomical classification of plant communities in Mt. Bulgok

\begin{tabular}{|c|c|c|c|}
\hline Plant communities & Area $\left(\mathrm{m}^{2}\right)$ & Relative area (\%) & Remarks \\
\hline Q. serrata-Q. mongolica & $1,372,805$ & 30.0 & \\
\hline Q. acutissima & 853,482 & 18.6 & \\
\hline Q. acutissima-Q. serrata & 740,520 & 16.2 & \\
\hline Q. serrata-Q. acutissima & 228,075 & 5.0 & \\
\hline Q. variabilis-Q. serrata community & 222,578 & 4.9 & \\
\hline P. rigida & 197,434 & 4.3 & \\
\hline Q. acutissima-C. crenata & 145,058 & 3.2 & \\
\hline R. pseudoacacia-Q. acutissima & 104,832 & 2.3 & \\
\hline L. leptolepis & 104,344 & 2.3 & \\
\hline C. crenata & 69,904 & 1.5 & \\
\hline P. koraiensis & 66,657 & 1.5 & \\
\hline Q. mongolica-Q. serrata & 54,181 & 1.2 & \\
\hline Q. acutissima-R. pseudoacacia & 36,472 & 0.8 & \\
\hline Prunus serrulata var. spontanea & 29,327 & 0.6 & \\
\hline C. crenata- $P$. rigida & 25,670 & 0.6 & \\
\hline Q. mongolica & 25,621 & 0.6 & \\
\hline R. pseudoacacia & 18,005 & 0.4 & \\
\hline Farm land & 285,280 & 6.2 & \\
\hline Total & $4,580,244$ & 100 & \\
\hline
\end{tabular}



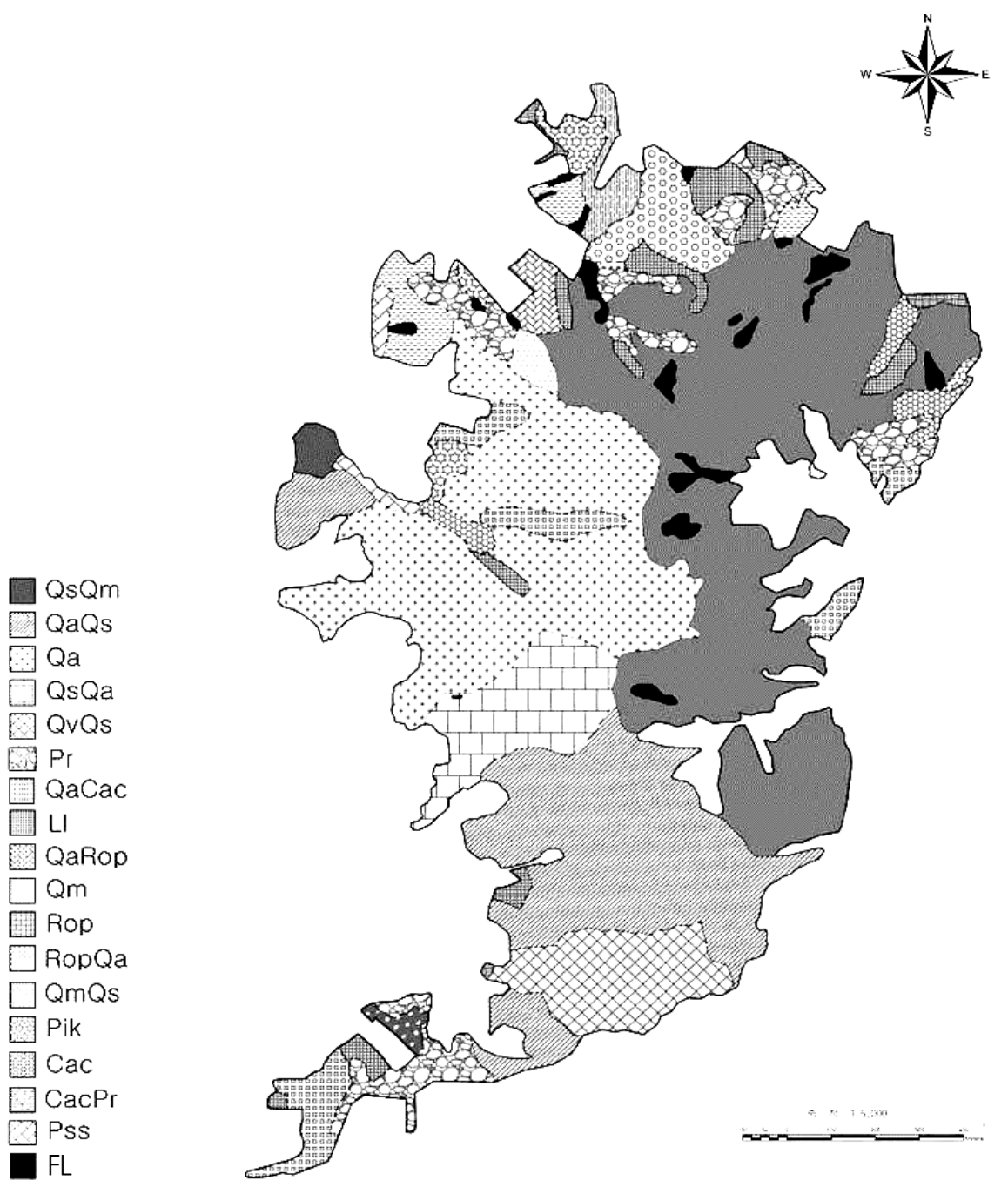

Fig. 4. Actual vegetation map of Mt. Bulgok.

QsQm, Q. serrata-Q. mongolica community; QaQs, Q. acutissima-Q. serrata community; Qa, Q. acutissima community; QsQa, Q. serrata-Q. acutissima community; QvQs, $Q$. variabilis-Q. serrata community; $\operatorname{Pr}, P$. rigida community; QaCac, Q. acutissima-C. crenata community; Ll, L. leptolepis community; QaRop, Q. acutissima-R. pseudoacacia community; Qm, Q. mongolica community; Rop, R. pseudoacacia community; RopQa, R. pseudoacacia-Q. acutissima community; QmQs, Q. mongolica-Q. serrata community; Pik, P. koraiensis community; Cac, C. crenata community; CacPr, C. crenata-P. rigida community; Pss, Prunus serrulata var. spontanea community; Fl, Farm land.

불곡산지역의 대체적인 식생의 분포를 보면 행정구역상 광주시 오포읍에 해당하는 능선의 동쪽 사면에 졸참나무-신갈나무군락이 주로 분포하고, 성남시 분당구에 해당하는 서쪽 사면과 상수리나무 -졸참나무군락, 상수리나무군락, 졸참나무-상수리나무군락 등이 주요 식생으로 분포한다. 불곡산의 북쪽 사면인 수내동 일대와 지역난방공사에 인접한 산림부에는 리기다소나무 군락, 일본잎갈나무군 락, 밤나무 군락 등 식재림이 자주 나타난다. 또한 조사지역의 남서쪽으로 주능선과 연결되는 낮은 
야산에는 리기다 소나무림이 비교적 넓게 분포한다. 비교적 평탄한 지형인 서쪽 사면에는 주로 골짜 기를 따라 농경지와 묵밭 등이 분포한다.

\section{2) 주요 군락의 구조}

\section{(1) 졸참나무-신갈나무군락}

졸참나무-신갈나무군락은 불곡산의 주능선 동쪽 사면에 주로 분포한다. 전체 식생면적의 $30.0 \%$ 로 가장 넓은 면적을 차지하는 군락으로 교목층, 아교목충, 관목층, 초본층의 4층 구조를 나타내었다. 교 목층의 높이는 $10 \sim 14 \mathrm{~m}$ 였고, 평균 높이는 $12 \mathrm{~m}$ 였다. 아교목층의 평균높이는 $6.5 \mathrm{~m}$ 였으며, 관목층은 평 균 $2.5 \mathrm{~m}$, 초본층의 평균높이는 $0.4 \mathrm{~m}$ 였다. 교목층은 졸참나무와 신갈나무가 출현하였고, 아교목층의 우점종은 팥배나무와 졸참나무였다. 아교목층에서 우점종과 함께 출현한 종은 벚나무, 밤나무였다. 관목층의 우점종은 진달래였으며, 수반종은 팥배나무, 노간주나무, 벚나무, 졸참나무, 때죽나무, 밤나 무, 신갈나무였다. 초본층의 우점종은 주름조개풀과 큰기름새였으며, 상수리나무, 노루발, 진달래, 그 늘사초, 맑은대쑥, 청가시덩굴, 개옻나무, 노간주나무, 노린재나무, 청미래덩굴, 상수리나무, 잣나무가 함께 출현하였다.

신갈나무군락의 층별 식피율은 교목층이 $85 \%$, 아교목층 $10 \%$, 관목층 $30 \%$, 초본층이 $7.5 \%$ 를 나타 내었으며(Fig. $5 \mathrm{~A}$ ) 교목층 우점종의 $\mathrm{DBH}$ 는 $13 \sim 37 \mathrm{~cm}$ 로 다양하게 나타났다.

\section{(2) 상수리나무군락}

상수리나무군락은 불곡산의 서쪽 사면에 해당하는 성남시 분당구의 정자동과 분당 서울대병원 인 근에 넓게 분포한다. 전체식생면적의 $18.6 \%$ 를 차지한다. 잣나무나무군락의 층위구조는 4 층으로 층위 별 식피율은 교목층 $95 \%$, 아교목층 $50 \%$, 관목층 $60 \%$, 초본층 $5 \%$ 를 나타내었다(Fig. $5 \mathrm{~B}$ ). 교목층의 높이는 $12 \mathrm{~m}$ 였으며, 나머지 층별 높이는 아교목층은 $7 \mathrm{~m}$, 관목층은 $2.5 \mathrm{~m}$, 초본층은 $0.2 \mathrm{~m}$ 였다. 교목층 은 상수리나무가 우점하였으며, 서어나무, 소나무가 함께 출현하였다. 아교목층은 상수리나무와 서 어나무가 우점하였고, 소나무가 수반종으로 출현하였다. 관목층은 때죽나무와 진달래가 우점하고, 상수리나무, 생강나무, 서어나무, 쥐똥나무, 회목나무, 떡갈나무, 쪽동백나무, 가막살나무 등이 출현 하였다. 초본층의 우점종은 진달래였으며, 큰기름새, 때죽나무, 쥐똥나무, 맥문동, 가막살나무, 청가 시덩굴, 그늘사초, 잣나무, 청미래덩굴, 물박달, 노린재나무, 잣나무, 갈참나무, 칡, 회목나무가 함께 자라는 것으로 나타났다.

\section{(3) 상수리나무-졸참나무군락}

상수리나무-졸참나무군락은 성남시 분당구의 구미동에 해당하는 불곡산의 남서쪽 사면에 주로 분 포한다. 전체 식생면적의 $16.2 \%$ 를 차지한다. 잣나무나무군락의 층위구조는 4 층으로 층위별 식피율은 교목층 $95 \%$, 아교목층 $50 \%$, 관목층 $60 \%$, 초본층 $5 \%$ 를 나타내었다(Fig. $5 \mathrm{~B}$ ). 교목층의 높이는 $11 \mathrm{~m}$ 였 으며, 나머지 층별 높이는 아교목층은 $6 \mathrm{~m}$, 관목층은 $2.3 \mathrm{~m}$, 초본층은 $0.5 \mathrm{~m}$ 였다. 교목층의 우점종은 상수리나무가 최우점하고, 두 번째로 높은 식피율을 보였다. 아교목층은 졸참나무가 우점하였으며, 


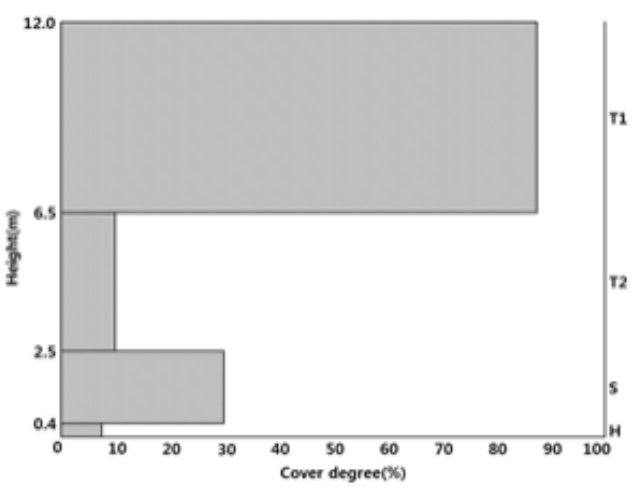

(A)

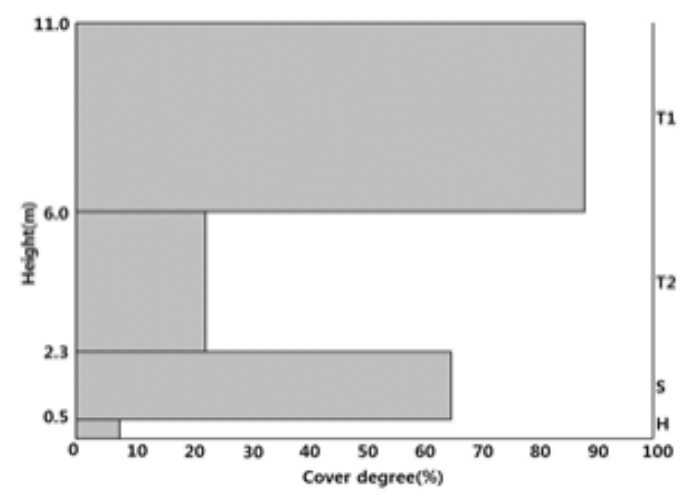

(C)

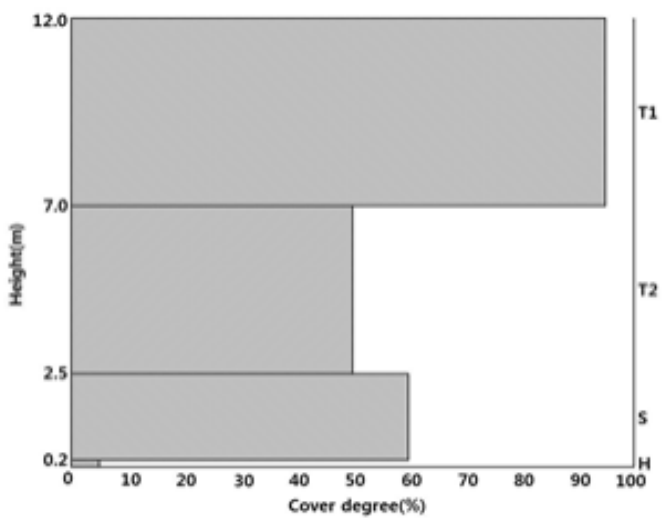

(B)

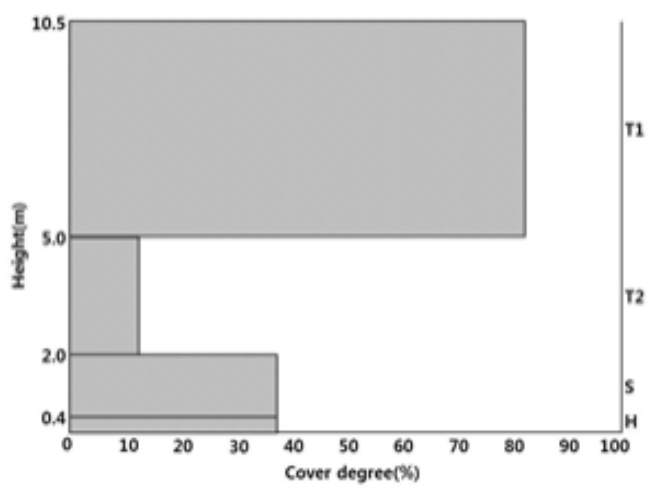

(D)

Fig. 5. Vertical structure and coverage of major plant communities of Mt. Bulgok. (A) Q. serrata-Q. mongolica community; (B) Q. acutissima community; (C) Q. acutissima-Q. serrata community, (D) $P$. rigida community.

밤나무, 때죽나무가 동반하여 출현하였다. 관목층의 우점종은 생강나무였으며, 때죽나무, 개옻나무, 노린재나무, 팥배나무, 국수나무가 수반종으로 출현하였다. 초본층의 우점종은 노간주나무였으며, 생 강나무, 으름덩굴, 졸참나무, 상수리나무, 때죽나무, 덜꿩나무, 칡, 청가시덩굴, 주름조개풀, 고사리, 맑은대쑥, 그늘사초가 함께 자라는 것으로 나타났다.

\section{(4) 리기다소나무군락}

리기다소나무군락은 조사지역중 북쪽 사면의 시가지와 인접한 곳에 주로 출현하였다. 식재림 중 에서 가장 넓게 분포하였으며, 전체 면적중 $4.3 \%$ 를 차지하였다. 군락의 수직구조는 교목층, 아교목 층, 관목층, 초본층의 4 층 구조였다. 층별 평균 식피율은 교목층이 $80 \%$, 아교목층 $12.5 \%$, 관목층 $37.5 \%$, 초본층이 $37.5 \%$ 였다. 교목층의 평균 수고는 $10.5 \mathrm{~m}$ 이고, 아교목층은 평균 $5 \mathrm{~m}$, 관목층은 평균 $2 \mathrm{~m}$, 초본층은 평균 $0.4 \mathrm{~m}$ 였다(Fig. $5 \mathrm{C}$ ). 층별 출현종을 살펴보면, 교목층은 우점종인 리기다소나무 이 


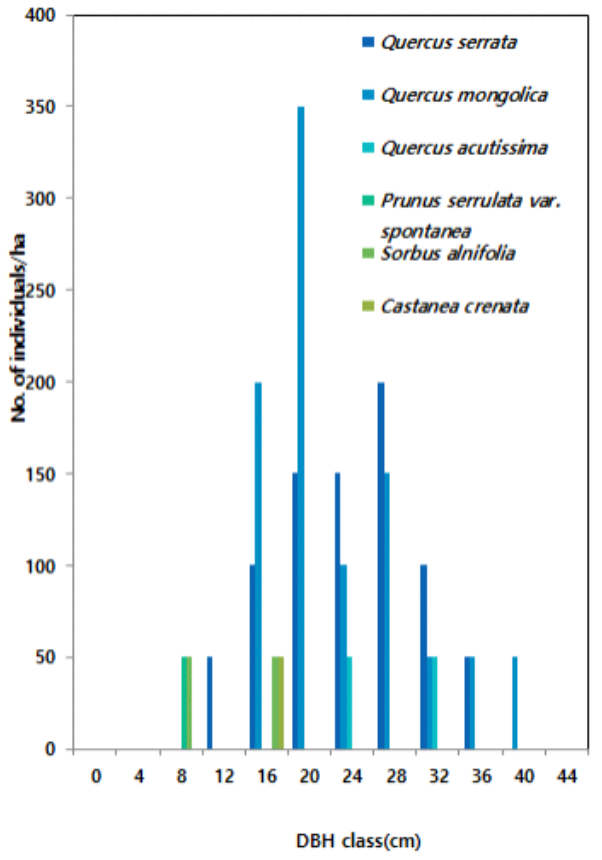

(A)

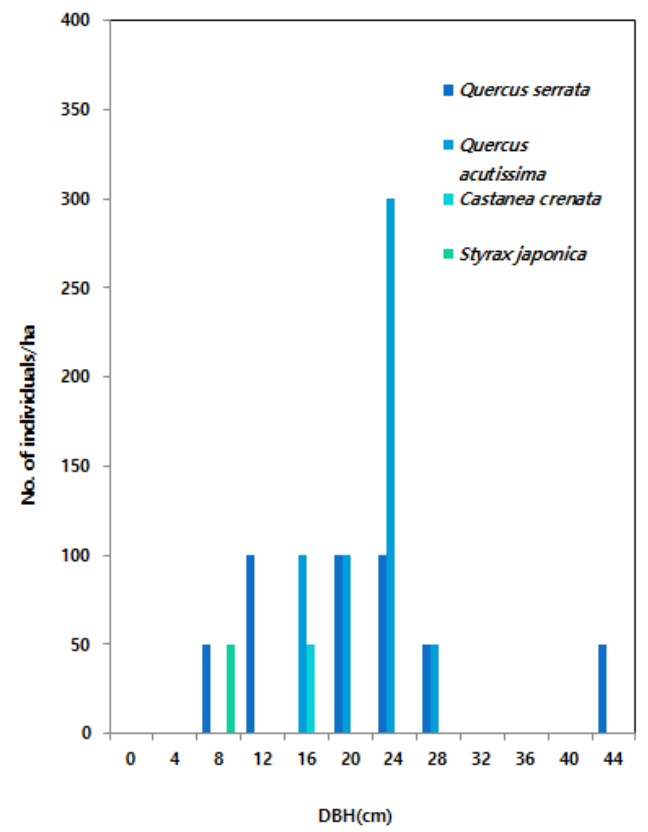

(C)

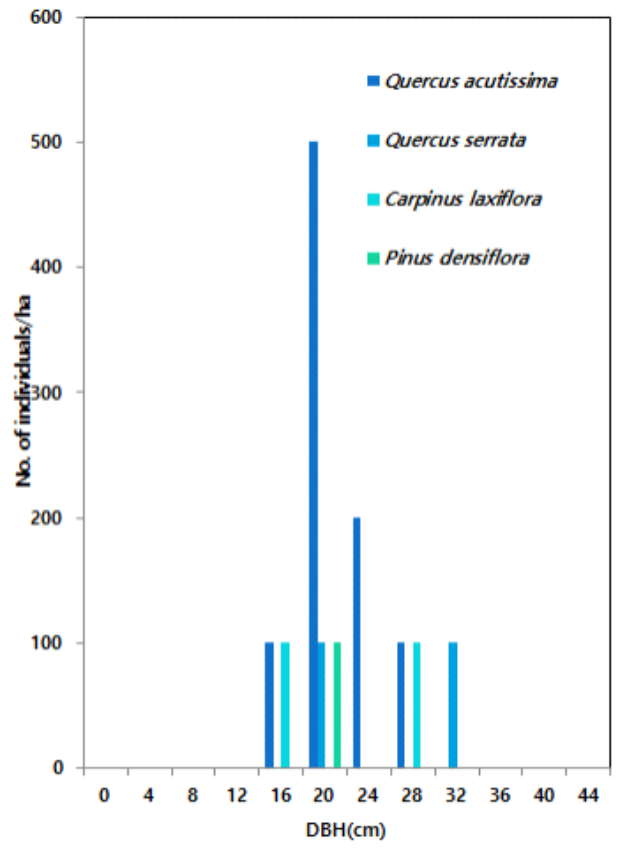

(B)

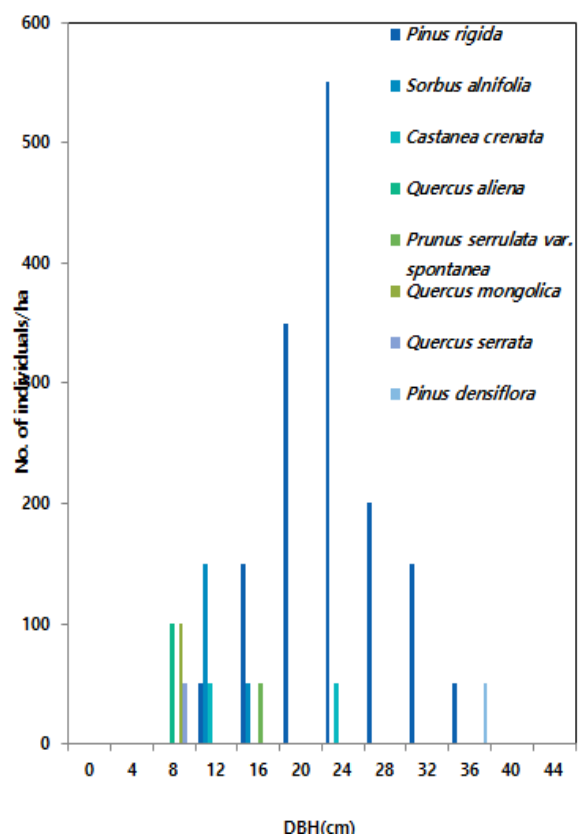

(D)

Fig. 6. Frequency distribution of $\mathrm{DBH}$-class of dominant tree species in each main plant community of Mt. Bulgok. (A) Q. serrata-Q. mongolica community; (B) Q. acutissima community; (C) $Q$. acutissima- $Q$. serrata community; (D) P. rigida community. 
외에 팥배나무, 밤나무, 소나무가 동반 출현하였다. 아교목층의 우점종은 갈참나무와 신갈나무였고, 수반종은 밤나무, 졸참나무가 있었다. 관목층에는 국수나무와 진달래가 우점하였고, 갈참나무, 개옻 나무, 노간주나무, 밤나무, 팥배나무 등이 동반 출현하였다. 초본층의 우점종은 애기나리와 주름조개 풀이고, 수반종은 개옻나무, 쥐똥나무, 잣나무, 리기다소나무, 상수리나무, 청가시덩굴 등이었다.

\section{3) DBH Class별 빈도 분포}

불곡산의 주요 식물군락의 DBH-Class 분포를 분석한 결과, 가장 넓은 식생면적을 차지하는 졸참나 무-신갈나무군락에서 졸참나무는 $13 \sim 34 \mathrm{~cm}$ 의 흥고직경 분포를 나타내었고, 신갈나무는 $13 \sim 37 \mathrm{~cm}$ 의 흥고직경 분포를 나타내어 소경목에서 대경목까지 고른 분포를 보였다. 벚나무, 팥배나무, 밤나무 등 의 수반종 $8 \sim 20 \mathrm{~cm}$ 구간의 소경목에서 주로 출현하였고 개체수도 적었다. 따라서 본 군락은 당분간 신갈나무군락으로 유지될 것으로 예상된다(Fig. 6A).

상수리나무군락의 우점종인 상수리나무는 횽고직경이 $15 \sim 27 \mathrm{~cm}$ 까지 나타났으나, 직경 20 24cm 의 개체들이 월등히 많은 수를 차지하였다. 서어나무, 밤나무, 소나무 등 동반출현종 또한 $12 \mathrm{~cm}$ 까지 의 소경목은 나타나지 않았다. 따라서 이 군락은 당분간 상수리나무가 계속해서 우점할 것으로 보인 다(Fig. 6B).

상수리나무-졸참나무군락은 상수리나무는 흥고직경 분포가 $12 \sim 28 \mathrm{~cm}$ 의 중경목에 집중되어 나타 났으며, 이에 비해 졸참나무는 4 44cm까지 소경목에서 대경목까지 고른 분포를 나타내었다. 밤나무 와 때죽나무는 소수의 개체가 소경목으로 일부 출현하였다. 현재 상수리나무가 최우점하는 본 군락 은 흥고직경의 빈도 분포로 볼 때 앞으로도 상수리나무와 졸참나무가 우점할 것으로 생각된다(Fig. 6C).

리기다소나무군락의 우점종인 리기다소나무는 홍고직경이 12 36cm까지 나타났으나, 직경 16 $24 \mathrm{~cm}$ 의 개체들이 월등히 많은 수를 차지하였다. 소경목의 잣나무는 비교적 소수였다. 식재림인 리기 다소나무림은 대부분 유사한 흥고직경을 나타내는데, 식재 후 실생에 의한 차대 개체가 공급되지 않 아 소경목의 리기다소나무가 나타나지 않은 것으로 볼 수 있다. 졸참나무, 신갈나무, 벚나무 등 활엽 수종 소경목 개체가 분포하는 것으로 보아 장기적으로 볼 때 이들 수종에 의한 교체가 일어날 것으 로 예상되나, 인위적인 관리에 의해 현 상태를 유지할 가능성도 있는 것으로 보인다(Fig. 6B).

\section{3. 녹지자연도(Degree of Green Naturality)와 순일차생산량(NPP)}

녹지자연도는 수역을 포함한 육지지역을 식물군락의 자연성을 고려하여 등급화한 주제도로서, 등

Table 3. Distribution of green naturality degrees (DGN) of Mt. Bulgok

\begin{tabular}{crc}
\hline DGN & Area $\left(\mathrm{m}^{2}\right)$ & Ratio(\%) \\
\hline DGN [2] & 285,280 & 6.2 \\
DGN [6] & 582,742 & 12.8 \\
DGN [7] & $3,712,221.7$ & 81.0 \\
\hline Total & $4,580,244$ & 100.0 \\
\hline
\end{tabular}


Table 4. The net primary production estimated by Miami and Montreal model

\begin{tabular}{cccc}
\hline Region & $\mathrm{A}\left(\mathrm{g} / \mathrm{m}^{2} /\right.$ year $)$ & $\mathrm{B}\left(\mathrm{g} / \mathrm{m}^{2} /\right.$ year $)$ & $\mathrm{C}\left(\mathrm{g} / \mathrm{m}^{2} /\right.$ year $)$ \\
\hline Seoul & $1,450.89$ & $1,764.62$ & $1,457.30$ \\
\hline
\end{tabular}

A, Miami model by mean annual temperature ; B, Miami model by mean annual precipitation ; C, Montreal Model.

The data from Yim (1982).

급이 높을수록 인간의 간섭이 배제되어 녹지의 자연성이 높다. 불곡산 지역의 녹지자연도는 Fig. 7 과 같으며, 이를 분석하면 Table 4와 같다.

분석 결과, 졸참나무-상수리나무군락, 상수리나무군락, 상수리나무-아까시나무군락 등 자연식생과 기타 자연림 기원의 군락인 DGN [7] 등급이 전체면적 대비 $81.0 \%$, 식재림을 포함한 인공림 기원의 지역인 DGN [6] 등급이 전체의 $12.8 \%$ 를 차지하고 있다. DGN [2] 등급에 해당하는 농경지는 주로 민 가에 인접한 곳에 나타났으며, 지형이 평탄한 동쪽 사면의 골짜기에 주로 분포하였다. 전체면적에 대 한 비율은 $6.2 \%$ 였다.

조사지역의 생태계 기능의 척도인 순일차생산량을 Miami Model에 따라 추정한 결과, 평균기온 적 용 시 $1,450.89 \mathrm{~g} / \mathrm{year}$, 연간 강수량 적용 시 $1,764.62 \mathrm{~g} / \mathrm{year}$ 가 추정되었고, Montreal Model에 따라 추정 한 결과는 $1,457.30 \mathrm{~g} / \mathrm{year}$ 로 나타났다(임, 1982).

\section{4. 위협 요인과 보존을 위한 제언}

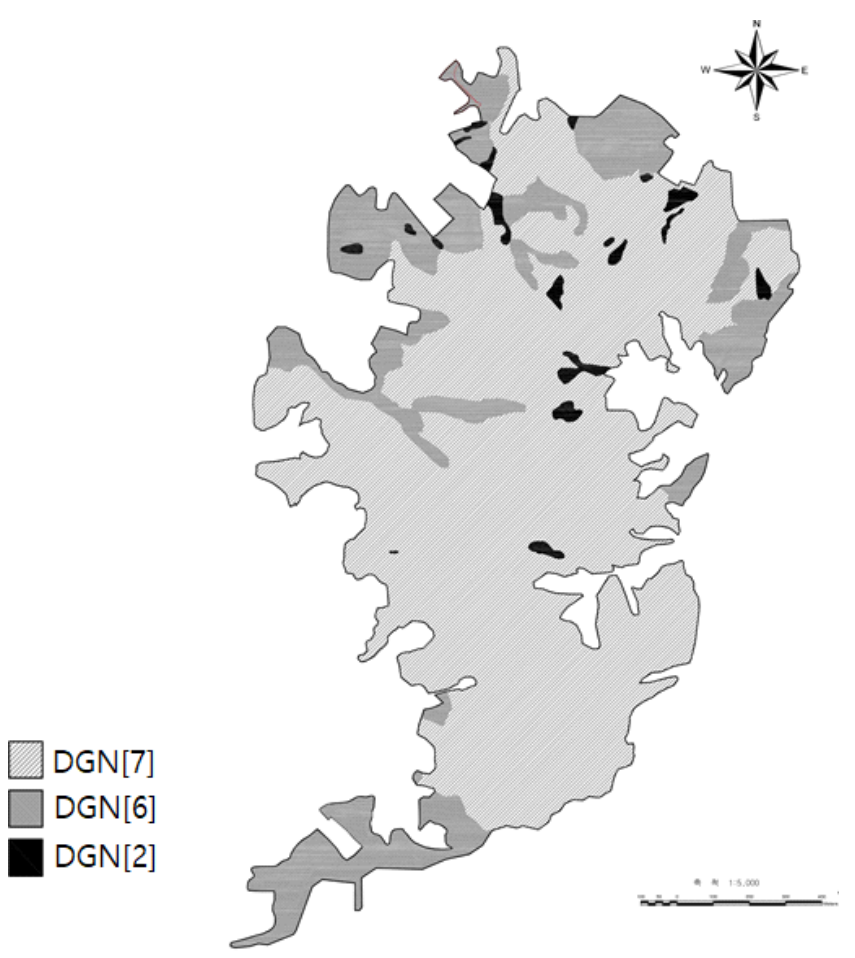

Fig. 7. Distribution of DGN at Mt. Bulgok. 
불곡산은 현재 비교적 양호한 자연식생이 분포하고 있으나 다양한 교란요인에 의해 위협받고 있 다. 이러한 위협요인의 근본적인 원인은 불곡산이 거대인구를 가진 성남시나 광주시와 같은 도시들 에 인접한 까닭이다. 대부분의 문제가 다수의 방문객과 주변 지역의 높은 개발압력에 의한 것으로 이를 정리하면 다음과 같다.

첫째, 주변지역의 개발 압력이 높다. 특히 광주시에 해당하는 지역은 지형이 비교적 완만하여 계 곡을 중심으로 농경지와 비닐하우스 등의 가건물이 산 내부에 깊숙이 위치하고 있어 식생에 직접적 인 피해를 주고 있으며, 현재는 과거 주택들과 농경지가 점차 사라지고 아파트와 주택단지가 이를 대체하고 있는 과정에 있어 개발에 따른 식생의 파괴와 간접적인 교란이 심화될 가능성이 높다.

둘째, 불곡산을 방문하는 방문객의 수가 많다. 불곡산은 현재는 금지되어 있으나 과거에 산악오토 바이의 명소로 알려져 이를 즐기는 사람들이 많았으며 행글라이더 비행장이 있기도 했다. 또한 산책 과 하이킹 등을 위한 방문객의 수는 많은 편이다. 주요 등산로에는 불법적인 노점상이 존재하며, 이 노점상 주변은 낙엽 쓸기와 주변시설물 이용으로 인하여 등산로의 폭이 넓어지는 등 주변 식생에 악 영향을 주고 있다. 또한 가을에는 방문객들 중 일부가 참나무류의 열매인 도토리를 채취하기 위해 등산로를 벗어나기도 한다.

셋째, 비자연수종이 넓게 분포한다. 도심과 주택단지 인접부에 리기다소나무림, 일본잎갈나무림, 밤나무림, 벚나무림 등이 넓게 분포하고 있다. 이러한 수종들은 식생의 자연성을 낮추고, 주변지역으 로 퍼져나가 자연식생에 좋지 않은 영향을 줄 수 있다.

이러한 여러 가지 위협요인에 대해 자연식생을 보전하기 위해서는 우선 적절한 출입관리를 통해 방문객들에 의한 식생의 교란을 줄여야 한다. 이를 위해서는 등산로나 소로의 명확한 확립과 출입 제한구간 및 시설을 설정하는 것이 필요할 것으로 생각된다. 등산로와 도로의 경계를 정확히 설정하 고 펜스 등의 시설물을 적절히 배치하여야 할 것이다. 또한 도시 개발 시 솦을 파괴하는 과도한 개발 을 억제해야 한다. 개인 재산권과 자연보전의 적절한 타협을 통해 솦 파괴를 차단하는 것이 중요하 다. 식재수종의 확산을 방지하는 것도 필요할 것이다. 적절한 조경계획을 수립하여 식재림의 면적이 늘어나지 않게 하고, 필요에 따라서는 벌목 및 갱신작업을 고려해 볼 필요가 있다.

\section{인용문헌}

국가생물종정보시스템. www.nature.go.kr/

기상청. www.kma.go.kr/

이영노. 2002. 한국식물도감(원색). 교학사.

이창복. 1995. 대한식물도감. 향문사.

임양재, 이우철. 1978. 한반도 관속식물의 분포에 관한 연구. 한국식물학회지 8:1-33.

임양재. 1982. 한반도 순일차생산력의 추정. 중앙대학교 문리과대학보 제41호.

한국향토문화대전. http://www.grandculture.net/main/main.asp

환경부 환경공간정보서비스. www.egis.me.go.kr/

Yim, Y. J. and T. Kira. 1975. Distribution of forest vegetation and climate in the Korea penisula I. 
Distribution of some indices of thermal climate. J. Ecol. 25:77-88.

\section{요 약}

경기도 성남시와 광주시에 위치한 불곡산의 식생을 연구하기 위해 2017년 11월부터 2017년 12월 까지 식생조사를 실시하였고, 이를 바탕으로 현존식생도, 식생 수직 구조도, DBH-class, 녹지자연도 등을 작성하여 분석하였다. 식생 상관의 우점종에 근거해 분류된 불곡산의 주요 식생으로는 졸참나 무-신갈나무군락( $Q$. serrata-Q. mongolica community), 상수리나무군락( $Q$. acutissima community), 상수 리나무-졸참나무군락 $(Q$. acutissima- $Q$. serrata community), 졸참나무-상수리나무군락 $(Q$. serrata- $Q$. acutissima community), 굴참나무-졸참나무군락( $Q$. variabilis- $Q$. serrata community), 리기다소나무군락 (Pinus rigida community), 상수리나무-밤나무군락(Q. acutissima-C. crenata community), 아까시나무-상 수리나무군락(R. pseudoacacia-Q. acutissima community), 일본잎갈나무군락(L. leptolepis community)이 있었다. 졸참나무-신갈나무군락은 전체 식생면적의 $30.0 \%$ 를 차지하여 가장 넓은 면적을 점유하였고, 상수리나무군락, 상수리나무-졸참나무군락, 졸참나무-상수리나무군락이 그 뒤를 이었다. 불곡산 주요 식생의 수직구조는 교목층, 아교목층, 관목층, 초본층의 4층 구조였으며, 각 층의 식피율과 높이는 식 생의 유형에 따라 다양했다. DBH-class의 빈도분포의 분석결과, 졸참나무-신갈나무군락, 상수리나무 군락, 상수리나무-졸참나무군락은 외부의 간섭이 없을 경우 해당 군락을 유지할 것으로 예상되었다. 녹지자연도는 7 등급이 $81.0 \%, 6$ 등급 $12.8 \%, 2$ 등급이 $6.2 \%$ 를 나타내었다. 순일차생산량은 연평균 기 온을 반영한 Miami Model 적용 시 $1,450.81 \mathrm{~g} / \mathrm{m}^{2} / \mathrm{yr}$, Montreal model 적용 시 $1,457.30 \mathrm{~g} / \mathrm{m}^{2} / \mathrm{yr}$ 인 것으로 추정되었다. 불곡산의 식생을 보존하기 위해서는 방문객의 적절한 출입관리와 과도한 개발의 억제, 그리고 식재림에 대한 관리가 필요하다고 생각된다.

검색어 : 식생, 식물 군집, 불곡산, $\mathrm{DBH}-$ class 